Surv. Synth. Path. Res. 1985;4:I-V

\title{
Contents, Vol. 4, 1985
}

\section{Editor-in-Chief}

J.M. Cruse, Jackson, Miss.

Senior Editor

R.E. Lewis, Jr., Jackson, Miss.

Advisory Editors

M.M. Azar, Minneapolis, Minn. S. Azar, Minneapolis, Minn. A.B. Jenson, Washington, D.C.

Topic Editors

Inflammation and Repair H.Z. Movat, Toronto

Atherosclerosis and Cardiovascular Diseases

R.M. O’Neal, Jackson, Miss.

Cell Receptors

M.I. Greene, Boston, Mass.

Carcinogenesis and Cellular Injury

D. Kaufman, Chapel Hill, N.C.

Carcinogenesis

E. Farber, Toronto

Tumor Virology

W.H. Kirsten, Chicago, Ill.

Tumor Biology

M. Potter, Bethesda, Md.

Tumor Cell Biology

R.C. Gallo, Bethesda, Md.

Natural Killer Cells and Tumor Immunology

E. Lotzová, Houston, Tex.

Immunochemistry of Human Carcinomata

G.F. Springer, Evanston, Ill.

Neoplasia

W.W. Johnson, Jackson, Miss.

Pathogenesis of Infection

P. Bonventre, Cincinnati, Ohio

Immunopathology

M. Ginsberg, La Jolla, Calif. R. Ulevitch, La Jolla, Calif.

Hemostasis and Thrombosis

F.B. Taylor, Jr., Oklahoma City, Okla.

Cellular Injury, Ischemia and Shock B.F. Trump, Baltimore, Md. 
Muscle and Neurologic Disorders W.W. Tourtellotte, Los Angeles, Calif.

Pulmonary Diseases

J. Hayes, Boston, Mass.

Congenital Disorders

H.S. Rosenberg, Houston, Tex.

Metabolic and Endocrine Disorders P. Heitz, Basel

Toxicology

F. Homburger, Cambridge, Mass.

Reticuloendothelial System Pathophysiology

N.R. DiLuzio, New Orleans, La.

Bone Marrow Transplantation H. Shulman, Seattle, Wash.

Host Defense Mechanisms A.C. Issekutz, Halifax R. Bortolussi, Halifax

Cytopathology

S.D. Greenberg, Houston, Tex.

Nutrition

R.B. McGandy, Boston, Mass.

Aging

K. Hirokawa, Tokyo

Natural Immunity

G. Dennert, Los Angeles, Calif.

Clinical Pathology Reviews H. Rochman, Chicago, Ill.

S. Karger Medical and Scientific Publishers

Basel $\square$ München $\cdot$ Paris $\cdot$ London $\cdot$ New York $\cdot$ New Delhi $\cdot$ Singapore $\cdot$ Tokyo $\cdot$ Sydney

Drug Dosage

The authors and the publisher have exerted every effort to ensure that drug selection and dosage set forth in this text are in accord with current recommendations and practice at the time of publication. However, in view of ongoing research, changes in government regulations, and the constant flow of information relating to drug therapy and drug reactions, the reader is urged to check the package insert for each drug for any change in indications and dosage and for added warnings and precautions. This is particularly important when the recommended agent is a new and/or infrequently employed drug.

All rights reserved.

No part of this publication may be translated into other languages, reproduced or utilized in any form or by any means, electronic or mechanical, including photocopying, recording,

microcopying, or by any information storage and retrieval system, without permission in writing from the publisher or, in the case of photocopying, direct payment of a specified fee to the Copyright Clearance Center (see 'Information for Readers and Subscribers').

(C) Copyright 1985 by

S. Karger AG, P.O. Box, CH-4009 Basel (Switzerland) Printed in Switzerland by Thür AG

Offsetdruck, Pratteln

Contents Vol. 4,1985

No. 1 Interpretive Reviews

Immunology of Viral Diabetes

Babu, P.G.; Huber, S.A.; Craighead, J.E 1

Role of Papilloma Virus in Proliferative Squamous Lesions

Bennett Jenson, A.; Lim, L.Y.; Lancaster, W.D 8 
Host Defenses in Patients with Cystic Fibrosis: Modulation by Pseudomonas aeruginosa Speert, D.P 14

Route of Pseudomonas and Diphtheria Toxin Entry into Mammalian Cells: Basis for Sus ceptibility to Toxin

Morris, R.E.; Saelinger, C.B 34

Margination and Emigration of Leucocytes

Colditz, I.G 44

Mechanism of Cell-Mediated Cytolysis by Natural Killer Cells

Dennert, G 69

Autologous Bone Marrow Transplantation in Acute Leukemia

Dicke, K.A.; Vellekoop, L.; Zander, A.; Jagannath, S.; Poynton, C; Lichtiger, B.; Verma, D.S.; Spitzer, G 84

No. 2 Tumor Immunology

Structural and Functional Properties of Ganglioside Antigens on Human Tumors of Neuroectodermal Origin

Cheresh, D.A 97

Metabolic and Endocrine Disorders

Islet Pathology and the Pathogenesis of Type 1 and Type 2 Diabetes mellitus Revisited

Klöppel, G.; Löhr, M.; Habich, K.; Oberholzer, M.; Heitz, P.U 110

Inflammation

Acute Phase Response in Infectious Disease

Gauldie, J.; Lamontagne, L.; Stadnyk, A 126

Pathogenesis of Infection

The Microbiology and Pathogenesis of Pseudomembranous Colitis

Bartlett, J.; Laughon, B.E 152

Anatomic Pathology

Ultrastructural Characterization of Pulmonary Neoplasms. II. The Role of Electron Micros copy in Characterization of Uncommon Epithelial Pulmonary Neoplasms, Metastatic

Neoplasms to and from Lung, and Other Tumors, including Mesenchymal Neoplasms

Herrera, G.A.; Alexander, C.B.; Jones, J.M 163

IV Contents

No. 3 Autoimmunity

Autoimmunity to Cell Membrane Receptors (With 1 color plate)

De Baets, M.H.; Breda Vriesman, P.J.C. van 185

Immunopathology

Immunopathology Associated with Human Lymphotropic Retroviruses

Ruscetti, F.W 216

Cellular Differentiation

Senescent Cell Antigen: A Terminal Differentiation Antigen

Kay, M.M.B 227

Cellular Immunology

Multiparameter Analysis of Human Lymphocyte Subpopulations Using Flow Cytometry

Lewis, D.E.; Barren, K.S.; Miller, G.P.G.; Rich, R.R

Hypothesis and Theory

The Role of Calcium in Cell Injury and Repair: A Hypothesis

Trump, B.F.; Berezesky, I.K 248 
Pulmonary Diseases

Pulmonary Edema in Adult Respiratory Distress Syndrome

Wysolmerski, R.; Lagunoff, D 257

No. 4 Tumor Biology

Chromosomal in situ Hybridization and the Molecular Cytogenetics of Cancer

Emanuel, B.S 269

Cellular Differentiation

Chemical Induction of Tumor Cell Differentiation

Niles, R.M ， 282

Neoplasia

Spontaneous Regression and Cytodifferentiation of Cancer in Early Life: The Oncogenic

Grace Period

Bolande, R.P 296

Immunoprophylaxis

Protective Mechanisms of Experimental Vaccine-Induced Immunity to Pseudomonas

aeruginosa

Lieberman, M.M 312

Discussion on Methodology

Multiparameter Analysis of Immunohematological Disorders by Flow Cytometry

Duque, R.E.; Stoolman, L.M.; Hudson, J.L.; Ward, P.A 323

Contents V

No. 5-6 Atherosclerosis: Cells of the Vessel Wall (Part I), Symposium

Control of Reendothelialization: The Importance of Endothelial Microfilaments, Micro-tubules and Centrosomes in Endothelial Locomotion

Wong, M.K.K.; Gotlieb, A.I 341

Current Concepts of Vascular Endothelial and Smooth Muscle Cell Communication

Davies, P.F 357

A Comparison of Cultured Aortic Smooth Muscle Cells from Different Sources: Are They All the Same?

Mogayzel, P.J., Jr.; Faris, B.; Ely, R.; Franzblau, C 374

Synthesis and Turnover of Protein-Bound N'-Methylhistidine in Cultured Vascular Smooth

Muscle Cells

Hu, C.-L.; Toselli, P.; Franzblau, C 380

Metabolism of Lipoproteins Labeled with Fluorescent Indocarbocyanine Dyes for in vitro

Studies of Atherogenesis

Reynolds, G.D389

Autoimmunity

Mercury-Induced Autoimmune Glomerulonephritis in Inbred Rats. I. Kinetics and Species

Specificity of Autoimmune Responses

Michaelson, J.H.; McCoy, J.P., Jr.; Hirszel, P.; Bigazzi, P.E401

Mercury-Induced Autoimmune Glomerulonephritis in Inbred Rats. II. Immunohisto-

pathology, Histopathology and Effects of Prostaglandin Administration

Hirszel, P.; Michaelson, J.H.; Dodge, K.; Yamase, H.; Bigazzi, P.E 412

Inflammation 
Role of the Complement Anaphylatoxins in Inflammation and Hypersensitivity Reactions in the Lung

Stimler-Gerard, N.P 423

Cellular Immunology

Accessory Cell Function of a Lined Macrophage in the Induction of Suppressor T Cells in vitro

Nakamura, R.M.; Nakamura, Y.; Nagayama, A.; Tokunaga, T 443

Aging

Focal Lymphocytic Infiltration in Thyroids of Elderly People. Histopathological and Immunohistochemical Studies

Kurashima, C; Hirokawa, K 457

Author Index 467

Subject Index 468 